Journal of Epidemiology and Public Health (2018), 3(1): 50-59

https://doi.org/10.26911/jepublichealth.2018.03.01.04

\title{
Effects of Sexual Behavior, Family Support, Peer Support, Stigma, and Discrimination on Quality of Life Among Gay Community in Tulungagung, East Java
}

\author{
Dily Ekasari'), Argyo Demartoto²), Bhisma Murti1) \\ 1) Masters Program in Public Health, Universitas Sebelas Maret \\ 2) Department of Sociology, Faculty of Social and Political Sciences, Universitas Sebelas Maret
}

\begin{abstract}
Background: Stigma and discrimination that are experienced by gay community have long been documented to occur in Indonesia, including Tulungagung District, East Java. Gay community often experience stigma, discrimination, and rejection by the society and health personnel. Stigma and discrimination may worsen the quality of life among gay community. This study aimed to examine the effects of sexual behavior, family support, family income, peer support, stigma, and discrimination on quality of life among gay community in Tulungagung, East Java.

Subjects and Method: This was an analytic observational study with cross-sectional design. The study was conducted at Pelangi Gay Community, Tulungagung District, from October to November 2017. A total sample of 181 gays was selected by stratified random sampling. The exogenous variables were sexual behavior, family income, peer support, stigma, and discrimination. The endogenous variables were family support and quality of life. The data were collected by questionnaire and analyzed by path analysis.

Results: Better quality of life was positively affected by safe sexual behavior $(b=1.32 ; 95 \% \mathrm{CI}=$ 0.18 to $2.46 ; \mathrm{p}=0.023)$ and strong family support $(\mathrm{b}=1.47 ; 95 \% \mathrm{CI}=0.42$ to $2.51 ; \mathrm{p}=0.006)$. Strong family support was positively affected by family income $(b=1.62 ; 95 \% \mathrm{CI}=0.97$ to $2.27 ; \mathrm{p}=$ o.001). Better quality of life was positively affected by participation in peer support program (b= 2.84; $95 \% \mathrm{CI}=1.77$ to $3.91 ; \mathrm{p}=0.001)$, freedom of stigma $(\mathrm{b}=1.11 ; 95 \% \mathrm{CI}=-0.04$ to $2.26 ; \mathrm{p}=$ $0.060)$, and freedom of discrimination $(b=1.43 ; 95 \% \mathrm{CI}=0.37$ to $2.48 ; \mathrm{p}=0.008)$.

Conclusion: Safe sexual behavior and strong family support have direct positive effect on the quality of life among gay community. Stigma and discrimination have indirect effect on lower quality of life among gay community.
\end{abstract}

Keyword: quality of life, sexual behavior, family support, stigma, discrimination, gay

\section{Correspondence:}

Dily Ekasari. Masters Program in Public Health, Universitas Sebelas Maret, Jl. Ir. Sutami 36 A, Surakarta 57126, Central Java. Email: dilyekasari89@gmail.com.

\section{BACKGROUND}

Quality of life has a meaning of a good life or living conditions with high quality (Ventegodt et al., 2003). The gay community is a minority group that has different sexual orientation from the community, which affects unhealthy behavior and quality of life (Patrick et al., 2013).

The stigma and discrimination experienced by gays have been documented worldwide as causing a decline in the quality of life in gay communities (Patrick et al., 2013; Zahn et al., 2016; Albuquerque et al., 2016).

The result of the study by Rao et al. (2012) in China showed that high stigma had a relationship with depressive symptoms and led to a lower quality of life. Conversely, effective family support could improve the mental well-being and lead the gay community to have healthy behavior. Individuals who lacked family support were 
more likely to have unsafe sex behavior (Rao et al., 2012).

A survey conducted by the Ministry of Health of the Republic of Indonesia in 13 cities in Indonesia from 2009 to 2013 showed that the number of gays increased dramatically. In 2009 the number of gays was $7 \%$ which increased to $12.8 \%$ in 2013 . According to Gaya Nusantara, an LGBT organization in Indonesia, it was estimated that 2.6 million of East Java's six million people were same-sex enthusiasts (Dalmeri, 2016). A preliminary study conducted in Tulungagung District, East Java, estimated the gay population in the district by 2017 were 350 to 500 people (Forum Pelangi, 2017).

HIV infection in the gay community in western and eastern Asian countries is increasing. In China in 2013 it was found that $21.4 \%$ of the gay community were infected with HIV (Luo et al., 2015). Increased HIV infection and discrimination in the gay community is a warning to the HIV / AIDS control efforts (Qi et al., 2015; Hidru et al., 2016). Thousands of gay people living with HIV / AIDS and mostly dying from the disease are often considered unimportant by the family. Gay people are often rejected when visiting hospitals (Makadon et al., 2007).

In Tulungagung District, East Java, there were 22 gay people infected with HIV by 2015 and rising to 31 in 2016. This is an urgent issue that must be addressed immediately (the District AIDS Commission of Tulungagung, 2017).

Peer Support Group (KDS) is a gathering group of gay, where they help each other, share information, and support each other. The peer support group is expected to reduce the physical and mental burden of the group member. The participation of peer support may be used as an intervention to address quality of life issues of the gay community (Kurniasari et al., 2016; Demartoto et al., 2016).

Based on this background, the author was interested to investigate the influence of sexual behavior, family support, family income, peer support group, stigma, and discrimination, on the quality of life of the gay community in Tulungagung regency, East Java.

\section{SUBJECTS AND METHOD \\ 1. Study design \\ This was an analytic observational study with a cross-sectional design. The study was conducted at Pelangi gay community, Tulungagung, East Java, from October to November 2017. A sample of 181 gays was selected for this study by stratified random sampling. \\ The inclusion criteria in this study were gay residing in the Pelangi Commu- nity, Tulungagung, East Java, willing to follow research protocol, were able to read and write. The exclusion criteria were gays who resigned before the completion of the study and who were not available at the time of the study.}

\section{Study variables}

The dependent variable was quality life of gay. The independent variables were sexual behaviour, peer group support, stigma, discrimination, family income, and family support.

\section{Operational definition of variable}

Sexual behavior was defined as all sexual activity derived from sexual urges and followed by changes in physical signs such as engaging in sexual stimulant to gain satisfaction made with same-sex couples. The data were collected by questionnaire. The measurement scale was continuous, but for the purpose of data analysis it was transformed into dichotomous coded o for low risk of sexual behavior and 1 for high risk of sexual behavior. 
Family support was defined as the attitude or action performed by family members. The data were collected by questionnaire. The measurement scale was continuous, but for data analysis it was transformed into dichotomous coded o for weak family support and 1 for strong family support.

Family income was defined as the average of fixed and side income earned by the household head and family members in rupiah to meet the needs of daily living in the last 6 months. The data were collected by questionnaire. The measurement scale was continuous, but data analysis it was transformed into dichotomous coded o for low family income and 1 for high family income.

Peer group support was defined as participating support groups provide motivation and support for gays. The data were collected by questionnaire. The measurement scale was categorical coded o for did not participate and 1 for participated in peer group support.

Stigma was defined as an act of providing negative social labeling or stereotypes when talking about a person for the purpose of bad-mouthing. The data were collected by questionnaire. The measurement scale was continuous and then transformed into dichotomous coded o for stigma and 1 for no stigma.

Table 1. Sample characteristics

\begin{tabular}{|c|c|c|}
\hline Characteristic & Frequency (n) & Percent (\%) \\
\hline \multicolumn{3}{|l|}{ Age } \\
\hline$<25$ years & 77 & 42.5 \\
\hline$\geq 25$ years & 104 & 57.5 \\
\hline \multicolumn{3}{|l|}{ Marital status } \\
\hline Unmarried & 168 & 92.8 \\
\hline Married & 13 & 7.2 \\
\hline \multicolumn{3}{|l|}{ Education } \\
\hline$<$ Senior high school & 28 & 15.5 \\
\hline$\geq$ Senior high school & 153 & 84.5 \\
\hline \multicolumn{3}{|l|}{ Employment } \\
\hline Not employed & 44 & 24.3 \\
\hline Employed & 137 & $75 \cdot 7$ \\
\hline
\end{tabular}

Discrimination was defined as an the unjust or prejudicial treatment of different categories of people or things, especially on the grounds of race, age, sex, or physical condition. The data were collected by questionnaire. The measurement scale was continuous, but for data analysis it was transformed into dichotomous coded o for discrimination and 1 for no discrimination.

\section{Research ethics}

The research ethical clearance for this study was obtained from the Research Ethics Committee at Dr. Moewardi Hospital, Surakarta, Central Java, Indonesia. The research ethics included informed consent, anonymity, and confidentiality.

\section{Data analysis}

Path analysis was used to determine the magnitude of effect of direct and indirect variables on quality life among gay community. The path analysis proceeded through five steps including model specification, model identification, model fit, parameter estimation, and re-specification.

\section{Sample characteristics}

Sample characteristics are shown in Table 1. Table 1 shows that as many as 104 study subjects aged $\geq 25$ years old, 168 (92.8\%) unmarried, 153 (84.5\%) had education zsenior high school, and 137 (75.7\%) were employed. 
Table 2. Cross tabulation on the relationship between sexual behavior and quality of life

\begin{tabular}{lcccccc}
\hline \multirow{2}{*}{ Variable } & \multicolumn{2}{c}{ Quality of life } & & \multicolumn{2}{c}{ 95\% CI } & \multirow{2}{*}{ O5 } \\
\cline { 2 - 3 } & Poor (\%) & Good (\%) & OR & $\begin{array}{c}\text { Lower } \\
\text { bound }\end{array}$ & $\begin{array}{c}\text { Upper } \\
\text { bound }\end{array}$ & p \\
\hline $\begin{array}{l}\text { Sexual behavior } \\
\text { Risky }\end{array}$ & 75.9 & 24.1 & 8.28 & 4.23 & 16.19 & $<0.001$ \\
Not risky & 27.6 & 72.4 & & & & \\
\hline
\end{tabular}

Table 2 shows cross tabulation on the relationship between sexual behavior and quality of life. Percent of good quality of life was higher among gays with non risky sexual behavior than those with risky sexual behavior. Gays with risk non risky sexual behavior had 8 times more likely to have good quality of life than those with risky sexual behaviour $(\mathrm{OR}=8.28 ; 95 \% \mathrm{CI}=4.23$ to $16.19 ; \mathrm{p}<0.001)$. However, this is a crude estimate that is yet to be controlled for the effect of confounding factors.

Table 3. Cross tabulation on the relationship between family support and quality of life

\begin{tabular}{|c|c|c|c|c|c|c|}
\hline \multirow[b]{2}{*}{ Variable } & \multicolumn{2}{|c|}{ Kualitas Hidup } & \multirow[b]{2}{*}{ OR } & \multicolumn{2}{|c|}{$95 \% \mathrm{CI}$} & \multirow[b]{2}{*}{$\mathbf{P}$} \\
\hline & $\begin{array}{l}\text { Poor } \\
\text { (\%) }\end{array}$ & $\begin{array}{c}\text { Good } \\
\text { (\%) }\end{array}$ & & $\begin{array}{l}\text { Lower } \\
\text { bound }\end{array}$ & $\begin{array}{l}\text { Upper } \\
\text { bound }\end{array}$ & \\
\hline Family support & & & & & & \\
\hline Weak & 75.0 & 18 & 6.08 & 3.12 & 11.84 & $<0.001$ \\
\hline Strong & 33.0 & 73 & & & & \\
\hline
\end{tabular}

Table 3 shows cross tabulation on the relationship between family support and quality of life. Percent of good quality of life was higher among gays with strong family support than those with weak family support. Gays with strong family support had 6 times more likely to have good quality of life than those with weak family support $(\mathrm{OR}=6.08 ; 95 \% \mathrm{CI}=3.12$ to 11.84 ; $\mathrm{p}<0.001)$. However, this is a crude estimate that is yet to be controlled for the effect of confounding factors.

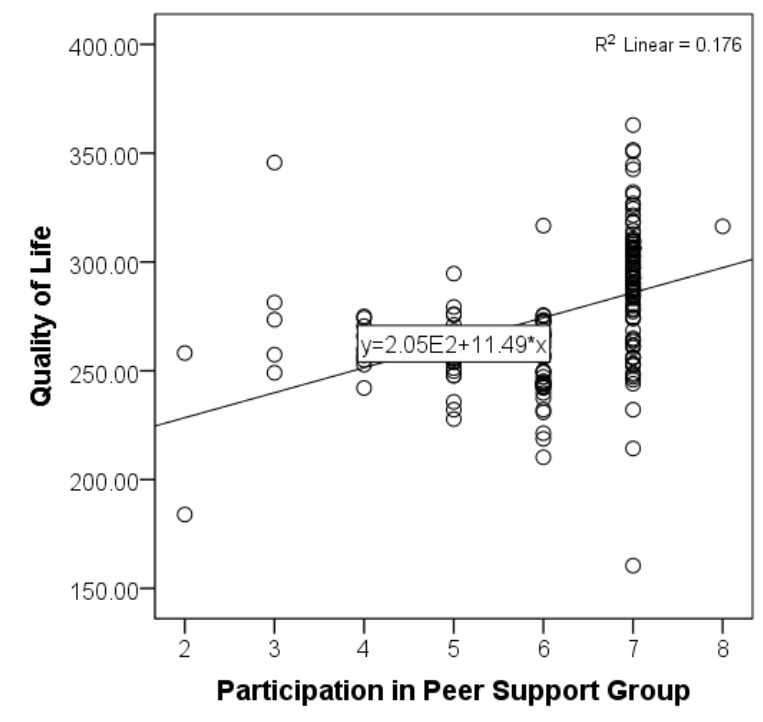

Figure 1. Scatter plot on the relationship between participation in peer support group and quality of life 
Journal of Epidemiology and Public Health (2018), 3(1): 50-59

https://doi.org/10.26911/jepublichealth.2018.03.01.04

Figure 1 shows scatter plot on the relationship between participation in peer support group and quality of life. It shows positive relationship between participation in peer support group and quality of life, suggesting that peer support group is beneficial to help improve the quality of life of its members.

\section{Path analysis}

Path analysis used Stata 13 program. Observed variables were 7 , endogenous variables were 2, and exogenous variables were 5. Degree of freedom was 14 (over identified and path analysis model can be done.
The structural model of path analysis with estimates is shown in Figure 2. Figure 2 shows the results of path analysis on the effects of sexual behavior, family support, family income, peer groups, stigma, and discrimination, on quality of life. The model in this study is in accordance with the sample data as indicated by the insignificant differences between the model specification and the saturation model. Since the model has been obtained in accordance with the sample data, it is not necessary to re-specify the path analysis model.

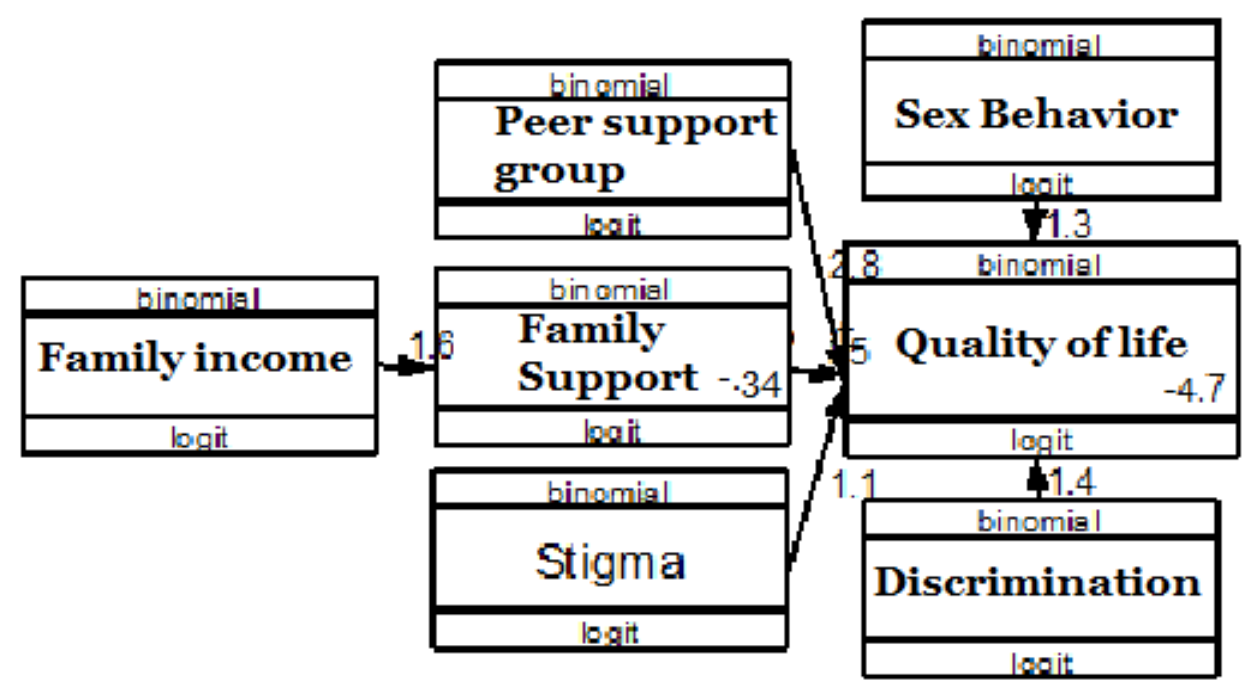

Figure 2. Structural model with estimation

Table 4. The results of path analysis on the quality of life determinants among gay community

\begin{tabular}{|c|c|c|c|c|c|c|}
\hline \multirow{2}{*}{$\begin{array}{c}\text { Dependent } \\
\text { variable }\end{array}$} & & \multirow[b]{2}{*}{ Independent variable } & \multirow{2}{*}{$\begin{array}{c}\text { Path } \\
\text { analysis } \\
\text { coefficient }\end{array}$} & \multicolumn{2}{|c|}{ 95\% CI } & \multirow[b]{2}{*}{$\mathbf{p}$} \\
\hline & & & & $\begin{array}{l}\text { Lower } \\
\text { limit }\end{array}$ & $\begin{array}{l}\text { Upper } \\
\text { limit }\end{array}$ & \\
\hline \multicolumn{7}{|l|}{ Direct effect } \\
\hline Quality life & $\leftarrow$ & Strong peer group support & 2.84 & 1.77 & 3.91 & $<0.001$ \\
\hline Quality life & $\leftarrow$ & Strong family support & 1.47 & 0.42 & 2.51 & 0.006 \\
\hline Quality life & $\leftarrow$ & Low risk sexual behaviour & 1.32 & 0.18 & 2.46 & 0.023 \\
\hline Quality life & $\leftarrow$ & Low stigma & 1.11 & -0.04 & 2.26 & 0.060 \\
\hline Quality life & $\leftarrow$ & Did not get discrimination & 1.43 & 0.37 & 2.48 & 0.008 \\
\hline Indirect effect & $\leftarrow$ & & & & & \\
\hline $\begin{array}{l}\text { Strong family support } \\
\text { N Observation }=181 \\
\text { Log likelihood }=-162.6\end{array}$ & $\leftarrow$ & High family income & 1.62 & 0.97 & 2.27 & 2.271 \\
\hline
\end{tabular}


Table 4 shows that strong peer support group $(b=2.84 ; 95 \% \mathrm{CI}=1.77$ to $3.91 ; \mathrm{p}=0.001)$, low risk sexual behavior $(b=1.32 ; 95 \% \mathrm{CI}=0.18$ to $2.46 ; \mathrm{p}=0.023)$, low stigma $(b=1.11 ; 95 \% \mathrm{CI}=-0.04$ to 2.26 ; $\mathrm{p}=0.060)$, did not get discrimination $(\mathrm{b}=$ $1.43 ; 95 \% \mathrm{CI}=0.37$ to $2.48 ; \mathrm{p}=0.008)$, strong family support $(\mathrm{b}=1.47 ; 95 \% \mathrm{CI}=$ 0.42 to $2.51 ; \mathrm{p}=0.006$ ), and high family income $(b=1.62 ; 95 \% \mathrm{CI}=0.97$ to $2.27 ; \mathrm{p}=$ o.o01) increased quality life of gay.

\section{DISCUSSION behaviour and quality life among gay community}

Sexual health is a physical, emotional, mental, and social well-being associated with sexuality (Poggiogalle et al., 2014). Sexual health can be achieved in the presence of healthy sexual behavior and not risky. The result of this study indicated that the safe sexual behavior of the gay community allowed them to have a good quality of life. Condom use protects against transmission of sexually transmitted diseases and HIV / AIDS. There is a strong relationship between healthy or non-risk sexual behavior with the high quality of life in human individuals (Thomas et al., 2015).

The result of this study indicated that gays with safe sexual behavior had a greater chance of having a good quality of life than gay with risky sexual behavior. The study by Flynn and Gow (2015) also showed that sexual behavior significantly affected the quality of life as it is the social and psychological domain of quality of life (Flynn and Gow, 2015).

\section{The association between family support and quality life of gay community}

The family is a social force that has an influence on the development of human behavior and the formation of personality.
The family plays a key role in the character building of family members. Mutual love, compassion, and caring, are a positive human development process for quality of life (Nascimento et al., 2016).

The quality of life domain affected by family support is the social domain. Gay who has good relationship and interaction with his family will get family support, which in turn will have an impact on improving the quality of life. The result of this study indicated that gay with strong family support had a greater likelihood of having a good living quality than gay with weak family support.

This study is supported by Liu et al. (2015) who reported that family support or social support was related to physical and mental health in both the general population and the individual. Social support can improve the mental well-being, prevent substance abuse, and promote healthy behavior for gays (Liu et al., 2015).

\section{The association between peer group support and quality life among gay community}

Gay communities are at risk for HIV infection because of their risky sexual behavior. Various HIV prevention efforts have attempted to reach all segments of society, including the gay community. The Peer Support Group (KDS) has been identified in the literature as an important mediator in addressing the effects of stigma and discrimination on gays. Peer support groups facilitated the exchange of opinions. Per support group also facilitated gays to participate in organizations or communities service for gays. By enhancing social relations, peer support group helps to increase knowledge and community acceptance of communities with different sexual orientations, and ultimately improve psychosocial well-being (Tomori et al., 2016). 
Journal of Epidemiology and Public Health (2018), 3(1): 50-59

https://doi.org/10.26911/jepublichealth.2018.03.01.04

According to Bantarti cit Demartoto (2017), Peer Support Group is a group with a close relationship consisting of individuals having certain similarities such as nature, purpose, and social status (Demartoto et al., 2017). Disclosure of sexual orientation in peer support groups provides additional resources for support in strengthening positive relationships and building more effective networks in support of peers with similar sexual orientations (Tomori et al., 2016). The result of this study indicated that gays participating in peer group support had a better quality of life than gays who are not participating in peer group support.

Quality of life increases because in this group each member mutually supports in the form of friendship and kinship. Other studies have also found that peer group support provides support for changes in risky sexual behavior (Prestage et al., 2016). In addition, peer support group helps behavior change through peer education (Demartoto et al., 2016).

\section{The association between stigma and quality life among gay community}

The stigma suffered by gay due to different sexual orientations leads to excessive stress. Stress in the minority is due to a form of prejudice, concealment of sexual orientation, discrimination, and self-stigma. Other stresses are discrimination in the workplace, stress in the family, social isolation, and prejudice accumulated during their lifetime (Prestage et al., 2016). Incorporation of stress in life is detrimental to health. The result of this study indicated that gay without stigma had a better quality of life than gay with stigma.

Stigma affects the psychological, environmental, and spiritual values of the quality of life. Another study revealed that each type of stigma is associated with every domain of quality of life. Research conducted by Charles et al (2012), suggests that severe stigma worsens the social domain of quality of life (Charles et al., 2012). The stigma of minorities in the form of bullying has a negative effect on the quality of life.

\section{The association between discrimi- nation and quality life among gay community}

Discrimination received by gay a minority takes the forms of sexual violence, physical violence, threats, humiliation, access to health services and social support. Discrimination causes feelings of sadness, distress, and thoughts of suicide. The incidence of discrimination in countries prohibiting homosexuality is reported to be quite high (Magno et al., 2017).

Discrimination significantly affects the quality of life, especially the mental health dimensions. Experience of discrimination and stigmatization greatly affects the occurrence of depression and anxiety. Discrimination against gays should not happen. Sexual orientation is common but not as a basis for discrimination (Mays and Cochran, 2001).

The result of this study indicated that gays who did not receive discrimination were more likely to have a better quality of life than gays who received discrimination. Discrimination makes life harder for them to live. Discrimination experiences result in negative psychological and physiological changes. The discrimination and stigma received by the gay community are rooted in political, economic, and ideological structures (Mays and Cochran, 2001).

The result of this study concludes that the quality of life in gays is directly influenced by sexual behavior, family support, peer support groups, stigma, and discrimination. Quality of life is indirectly affected by family income. 


\section{The association between family income and family support}

Economic and financial problems are factors that often cause a big effect on a family. A study puts that there is a relationship between socioeconomic position and quality of life (Nascimento et al., 2016). Low income can affect the quality of family life. The result of this study indicated that gays with high family income had a greater chance of a better quality of life, through better family support, than gays with low family income. Income allows individuals to meet the needs of life.

Lower family income has a negative impact on quality of life, as it limits life and so increases stress and lowers quality of life. Low family income leads to low family support, increased stress, and ultimately reduced the quality of life (Hawro et al., 2015).

\section{REFERENCE}

$\overline{\text { Albuquerque GA, Garcia CDL, Quirino S, }}$ Juscinaide M, Alves H, Belem JM, Winter F, et al. (2016). Access to Health Services by Lesbian, Gay, Bisexual, and Transgender Persons: Systematic Literature Review. BMC International Health and Human Rights, 1-10. doi: 10.1186/s12914-015-0072-9.

Charles B, Jeyaseelan L, Pandian AK, Sam AE, Thenmozhi $M$, Jayaseelan $V$ (2012). Association between Stigma, Depression and Quality of Life of People Living with HIV/AIDS (PLHA) in South India - A Community Based Cross Sectional Study, BMC Public Health, 12(1): 1. doi: 10.1186/14712458-12-463.

Dalmeri (2016) Proceding Tinjauan Terhadap Lesbian Gay Biseksual dan Transgender (LGBT) Dari Perspektif Hukum Pendidikan Dan Psikologi.
Available at: http:// metrouniv.ac.id/ uploaddata/file/66lgbt1. pdf.

Demartoto A, Soemanto RB, Zunariyah S (2016). Supporting and Inhibiting Factors in the Structured Peer Network among Housewives in Coping with HIV/ AIDS, 710: 424-427. doi: 10.2991/icse-15.2016.92.

Demartoto A, Zunariyah S, Soemanto RB (2017). Pendidikan Sebaya Terstruktur Responsif AIDS. Edited by A.K. Putra. CV.Kekata Group Surakarta.

Flynn TJ, Gow AJ (2015). Examining Associations between Sexual Behaviours and Quality of Life in Older Adults, Age and Ageing, 44(5): 823-828. doi: 10.1093/ageing/afvo83.

Forum Pelangi (2017). Hawro T, Zalewska A, Hawro M, Kaszuba A, Krolikowska $M$ and Maurer M. (2015). Impact of Psoriasis Severity on Family Income and Quality of Life, Journal of the European Academy of Dermatology and Venereology, 29(3): 438-443. doi: 10.1111/ jdv. 12572.

Hidru TH, Wang F, Lolokote S, Jia Y, Chen M, Tong W (2016). Associated Factors of Self-Reported Psychopathology and Health Related Quality of Life Among Men Who Have Sex With Men (MSM) with HIV/ AIDS in Dalian, China: A Pilot Study, Infectious Diseases of Poverty. 1-10. doi: 10.1186/s40249-0160204-z.

Komisi Penanggulangan AIDS Kabupaten Tulungagung (2017).

Kurniasari MA, Murti B, Demartoto A (2016). Association Between Participation in HIV/ AIDS Peer Group, Stigma, Discrimination, and Quality of Life of People Living with HIV/ AIDS, (September), 127-134.

Liu J, Qu B, Zhu Y, Hu B (2015). The Influence of Social Support on Quality of Life of Men Who Have Sex With Men 
Journal of Epidemiology and Public Health (2018), 3(1): 50-59

https://doi.org/10.26911/jepublichealth.2018.03.01.04

in China: A Preliminary Study, PLoS ONE, 1O(5): 1-10. doi: 10.1371/journal.pone.0127644.

Luo Y, Zhu C, Chen S, Geng Q, Fu R, Li X, $\mathrm{Xu}$ K, Cheng J, Ding J (2015). Risk Factors for HIV and Syphilis Infection among Male Sex Workers Who Have Sex With Men: A Cross-Sectional Study in Hangzhou, China, 2011, BMJ open, 5(4): eoo6791. doi: 10.1136/ bmjopen-2014-006791.

Magno L, Dourado I, Silva LAVD, Brignol S, Brito AMD, Guimaraes MDC, Benzaken A, Pinho A de A, Kendall C, Kerr LRF.S (2017) Factors Associated with Self-Reported Discrimination Against Men Who Have Sex With Men in Brazil, Rev Saude Publica, 51(102): 1-11. doi: 10. 11606/S1518-8787. 2017051000016.

Makadon MJ, Mayer KH, Potter J, Goldhammer H (2007). Fenway Guide to Lesbian, Gay, Bisexual, And Transgender Health, 2nd Edition.

Mays VM, Cochran SD (2001). Mental Health Correlates of Perceived Discrimination Among Lesbian, Gay, and Bisexual Adults in the United States, American Journal of Public Health, 91(11): 1869-1876. doi: 10.2105/ AJPH.91.11.1869.

Nascimento GB, Schiling NDO, Ubal SR, Biaggio EPV, Kessler TM (2016). Classificacao Socioeconômica e Qualidade de Vida de Familiares de Crianças e Adolescentes Com Deficiencia Auditiva, Revista CEFAC, 18(3): 657666. doi: 10.1590/1982-0216201618313215 .

Patrick DL, Bell JF, Huang JY, Lazarakis NC, Edwards TC (2013). Bullying and Quality of Life in Youths Perceived as Gay, Lesbian, or Bisexual in Washington State, 2010, American Journal of Public Health, 103(7): 1255-1261. doi:
10.2105/ AJPH. 2012. 301101.

Poggiogalle E, Lazzaro LD (2014). HealthRelated Quality of Life and Quality of Sexual Life in Obese Subjects, International journal, 847871. doi: 10.11$55 / 2014 / 847871$.

Prestage G, Brown G, Allan B, Ellard J, Down I (2016). Impact of Peer Support on Behavior Change Among Newly Diagnosed Australian Gay Men, JAIDS Journal of Acquired Immune Deficiency Syndromes, doi: 10.1097/ QAI. 0000000000001017.

Qi J, Zhang D, Fu X, Li C, Meng S, Dai M, Liu H, Sun J (2015). High Risks of HIV Transmission for Men Who Have Sex With Men - A Comparison Of Risk Factors of HIV Infection among MSM associated with Recruitment Channels In 15 Cities of China, PLoS ONE, 10(4): 1-14. doi: 10.1371/journal.pone.0121267.

Rao D, Chen WT, Pearson CR, Simoni JM, Fredriksen GK, Nelson K, Zhao H, Zhang F (2012). Social Support Mediates The Relationship between HIV Stigma and Depression/ Quality of Life among People Living with HIV in Beijing, China, International Journal of STD and AIDS, 23(7): 481-484. doi: $10.1258 /$ ijsa. 2009. 009428 .

Thomas H, Hess R, Thurston R (2015). Correlates of Sexual Activity and Satisfaction in Midlife ind Older Women, Annals of Family Medicine, 13(4): 336-342. doi: 10.1370/ afm. 1820.

Tomori C, Srikrishnan AK, Ridgeway K, Solomon SS, Mehta SH, Solomon S, Celentano DD (2016). Friends, Sisters, and Wives: Social Support and Social Risk in Peer Relationships among Men Who Have Sex With Men (MSM) in India, 8(5): 444-454. doi: 10.1158/1940-6207. CAPR-14-0359. 
Nrf2-dependent.

Ventegodt S, Merrick J, Andersen NJ (2003). Quality of Life Theory I. The IQOL Theory: An Integrative Theory of the Global Quality of Life Concept, The Scientific World JOURNAL, 3: 1030-1040. doi: 10.1100/tsw. 2003. 82.
Zahn R, Grosso A, Scheibe A, Bekker LG, Ketende S, Dausab F, Iipinge S, Beyrer C, Trapance G, Baral S (2016). Human Rights Violations among Men Who Have Sex with Men in Southern Africa: Comparisons Between Legal Contexts, PLoS ONE, 11(1): 1-12. doi: 10.1371/journal.pone.0147156. 